\title{
Heavy Metals in Water and Bottom Sediments of Odessa Region of the Black Sea
}

\author{
Sergey Yevgenevich Dyatlov \\ Institute of Marine Biology, Ukrainian National Academy of Sciences, Odessa 65011, Ukraine
}

\begin{abstract}
The paper presents the results of a comprehensive monitoring of the polygon: "Odessa Region, north-western part of the Black Sea" for the period 2009-2011. It is shown that most of the copper and nickel is brought into the sea from the catchment area, and zinc and cadmium are mainly of the autochthonous origin. It is found that in 2010, after heavy rains, the area of bottom sediments contaminated by copper and nickel was increased. The main source of copper in the sea is vast vineyards.
\end{abstract}

Keywords: Odessa Region of the Black Sea, water, bottom sediments, heavy metals, spatial distribution, GIS-based map technology.

\section{Introduction}

The Odessa Region of the Black Sea is the coastal zone of the sea near the megalopolis of Odessa (Ukraine) with the area of about $2685 \mathrm{~km}^{2}$. The maximum depth of the study area is 29 meters, minimum depth is 5 meters and the average depth is 15.17 meters. $20 \mathrm{~m}$ isobath is located at a distance of 2-3 $\mathrm{km}$ from the coastline [1].

The main sources of pollution of the Odessa Region of the Black Sea are the major seaports (Odessa, Illychevsk, Yuzhnyi), waste water of three treatment plants, drainage and rain waters, flow waters from Danube, Dniestr and Dniepr with Southern Bug. Since 1988 to present (except 1999-2004), Institute of Marine Biology has been carrying out the pollution monitoring in the Odessa Region of the Black Sea.

The coastal location of the polygon and its relative shallowness cause high variability of water temperature and salinity and sediment resuspension, which often lead to secondary contamination of water [2, 3].

Our previous studies describe bottom sediments of the Odessa Region of the Black Sea (Fig. 1), and the variability of annual average content of heavy metals

\footnotetext{
Corresponding author: Sergey Yevgenevich Dyatlov, Ph.D., research field: marine ecology. E-mail:sergey.dyatlov@gmail.com.
}

in bottom sediments from 1988 to the present time [4].

At the present time GIS-technology is increasingly being used for mapping the distribution of contaminants in sediments [5-7]. The goal of this work was the creation of the maps of heavy metals distribution in the Odessa Region of the Black Sea.

\section{Methodology}

Schematic map of the study area is shown in Fig.1. Bottom sediment samples were collected from the scientific boat "Sprut" and delivered to the analytical laboratory of OB IBSS. The content of heavy metals $(\mathrm{Cu}, \mathrm{Zn}, \mathrm{Ni}, \mathrm{Cd})$ in sediments was determined using flame photometry. Maps of the spatial distribution of heavy metals in sediments were created using the software MapInfo, ArcGIS and Corel Draw. It was selected 12 samples of bottom sediments in 2009 and 17 samples in 2010 and 2011.

In 2010, just prior to the expedition, there have been heavy rains across the north-western Black Sea, which led to a sharp increase copper and nickel in the sea [8]. In 2009, the precipitation was twice the norm, $740 \mathrm{~mm}$.

To assess the level of contamination of sediments with heavy metals, the excess over the background content of each of the metal was used of 1 (class 1 ש), 2 (class 2 ) and $3 \delta$ (class $3 \square$ ) Schematic map of the study area is shown in Fig.3. 


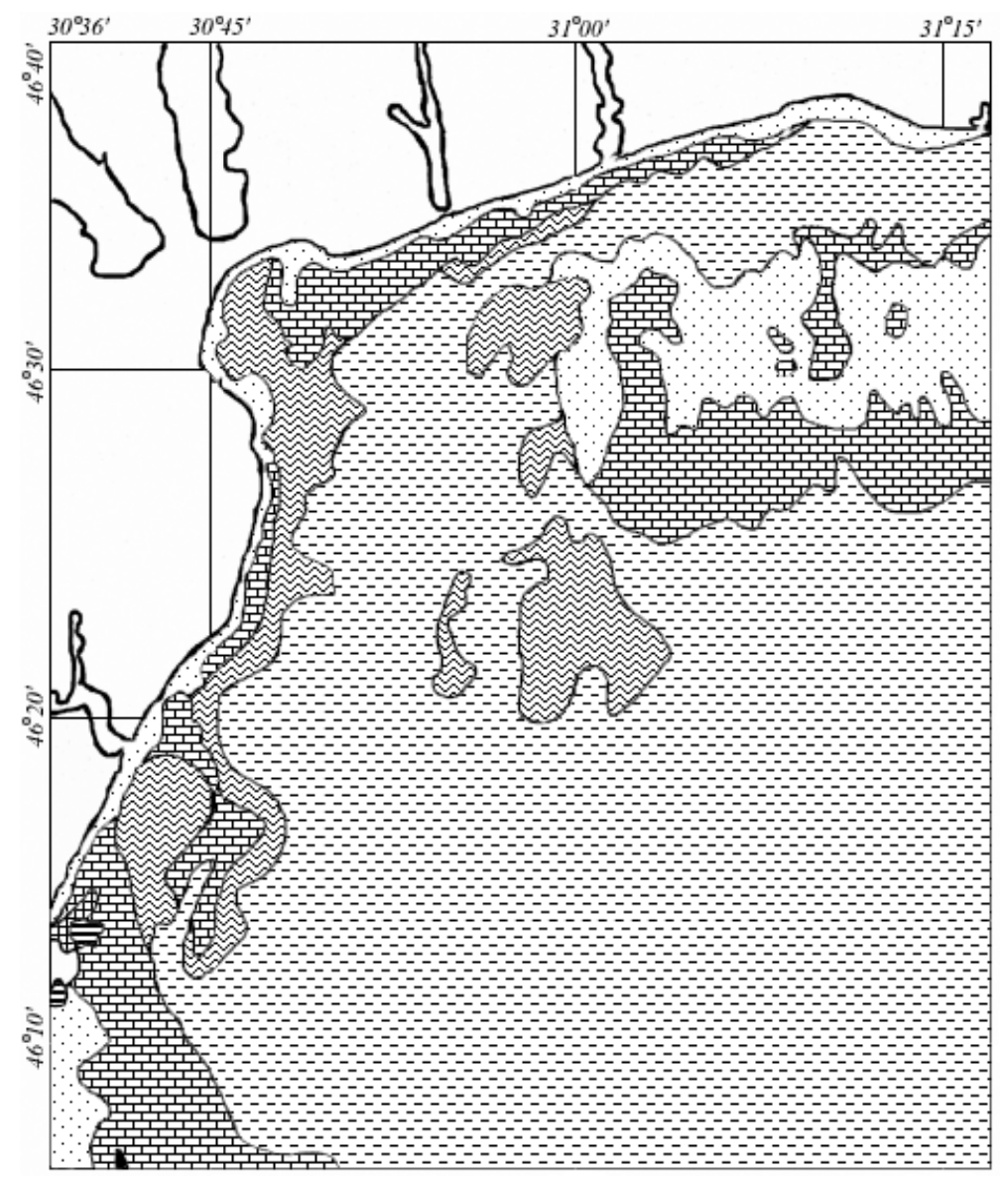

\begin{tabular}{|c|c|c|c|c|c|}
\hline 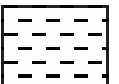 & Clayey silts & 册冊曲 & Pebble & $\therefore$ & Medium-fine sands \\
\hline 會 & Silts fine silt & & $\begin{array}{l}\text { Oolitic limestones } \\
\text { coquina }\end{array}$ & & Upper Pliocene sediments \\
\hline 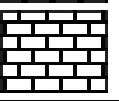 & Coquina & & Coquina limestones & 高喜-- & $\begin{array}{l}\text { Lithological boundaries } \\
\text { within the units }\end{array}$ \\
\hline
\end{tabular}

Fig. 1 The map of bottom sediments of the Odessa Region of the Black Sea.

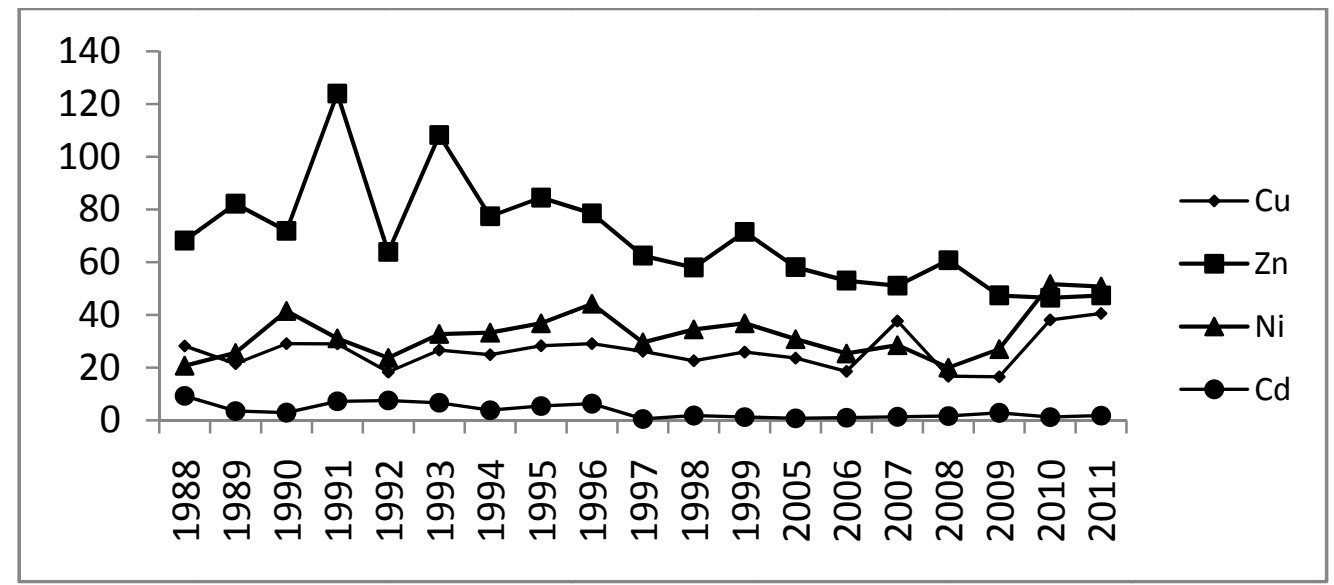

Fig. 2 Variability of annual average content of heavy metals in bottom sediments $\left(\mathrm{mkg}^{-1} \mathrm{~g}^{-1}\right.$ of solid matter) for the entire study period. 


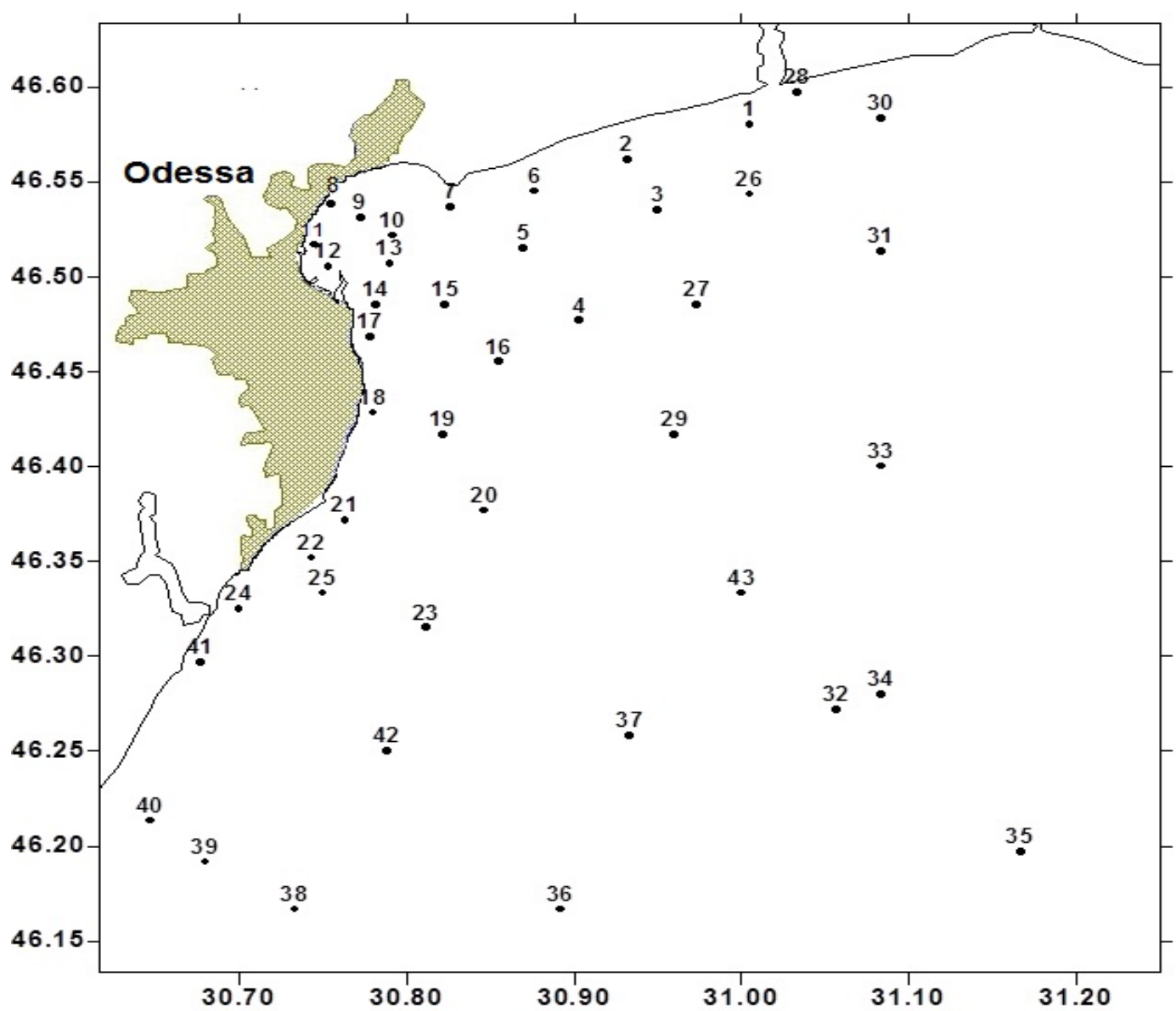

Fig. 3 A schematic map of the Odessa Region of north-west part of the Black Sea with sampling stations.

Table 1 Average and maximum content of heavy metals in water of the "Odessa Region of the Black Sea" polygon for the period 1988-2011.

\begin{tabular}{lllllllll}
\hline & \multicolumn{4}{c}{ The dissolved form, $\mathrm{m \kappa g} \cdot \mathrm{dm}^{-3}$} & \multicolumn{3}{c}{ Weighted form, $\mathrm{mKg}^{-3} \mathrm{dm}^{-3}$} \\
\cline { 2 - 10 } & $C u$ & $Z n$ & $N i$ & $C d$ & $C u$ & $Z n$ & $N i$ & $C d$ \\
\hline Surface horizon & & & & & & & \\
Min & 0.00 & 0.00 & 0.00 & 0.00 & 0.00 & 0.00 & 0.00 & 0.00 \\
Max & 36.37 & 111.60 & 11.10 & 45.40 & 43.35 & 121.38 & 28.81 & 18.10 \\
cp. & 1.86 & 10.30 & 1.143 & 0.67 & 0.73 & 7.20 & 1.08 & 0.23 \\
Mean & $\mathrm{n}=757$ & $\mathrm{n}=758$ & $\mathrm{n}=758$ & $\mathrm{n}=735$ & $\mathrm{n}=719$ & $\mathrm{n}=719$ & $\mathrm{n}=723$ & $\mathrm{n}=716$ \\
\hline Bottom horizon & & & & & & & & \\
\hline min & 0.02 & 0.00 & 0.00 & 0.00 & 0.00 & 0.00 & 0.00 & 0.00 \\
Max & 26.65 & 211.12 & 21.42 & 17.54 & 19.98 & 131.94 & 29.38 & 1.31 \\
cp. & 3.03 & 14.76 & 2.25 & 0.32 & 1.60 & 9.04 & 1.40 & 0.19 \\
Mean & $\mathrm{n}=765$ & $\mathrm{n}=764$ & $\mathrm{n}=764$ & $\mathrm{n}=743$ & $\mathrm{n}=718$ & $\mathrm{n}=720$ & $\mathrm{n}=715$ & $\mathrm{n}=720$ \\
\hline
\end{tabular}

\section{Results}

Table 1 shows the average and maximum values of heavy metals over the entire study period. The minimum metal content is zero, except for the dissolved form of $\mathrm{Cu}$ in the bottom layer $(0.02$ $\left.\mathrm{m \kappa g} \cdot \mathrm{dm}^{-3}\right)$.

The annual average concentration of heavy metals in sediments for the entire study period showed a tendency to decrease the content of $C u, Z n$ and $C d$, and content of $N i$ to grow in 2009. In 2010 the content of heavy metals flowing from rain waters into the waters 

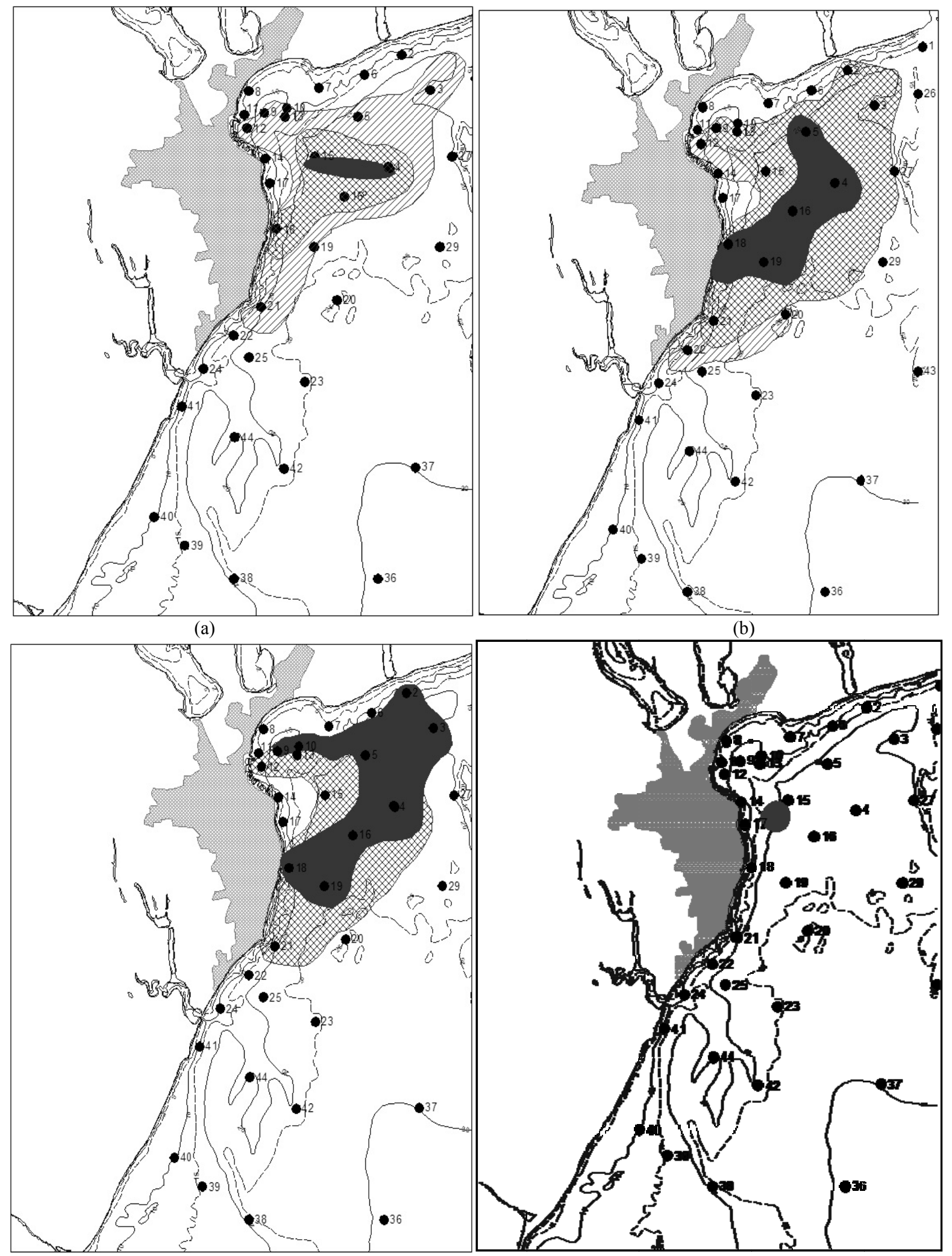

(c)

(d)

Fig. 4 Spatial distribution: A: copper, B: zinc, C: nickel, D: cadmium in Odessa Region of the Black Sea in 2009. 


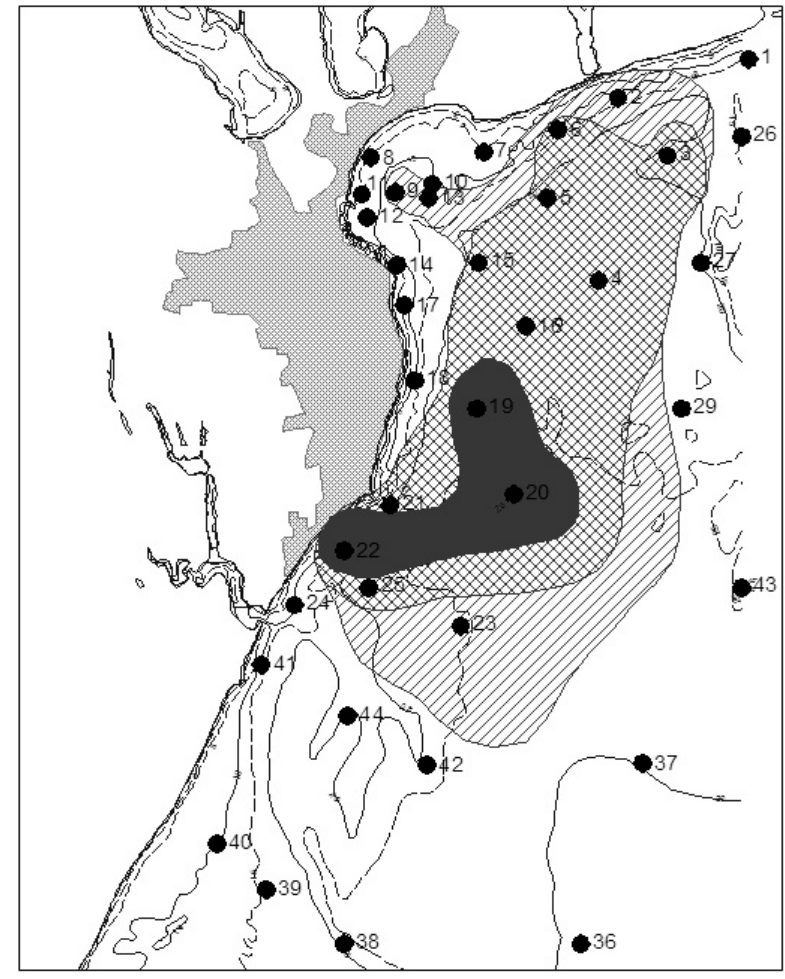

(a)

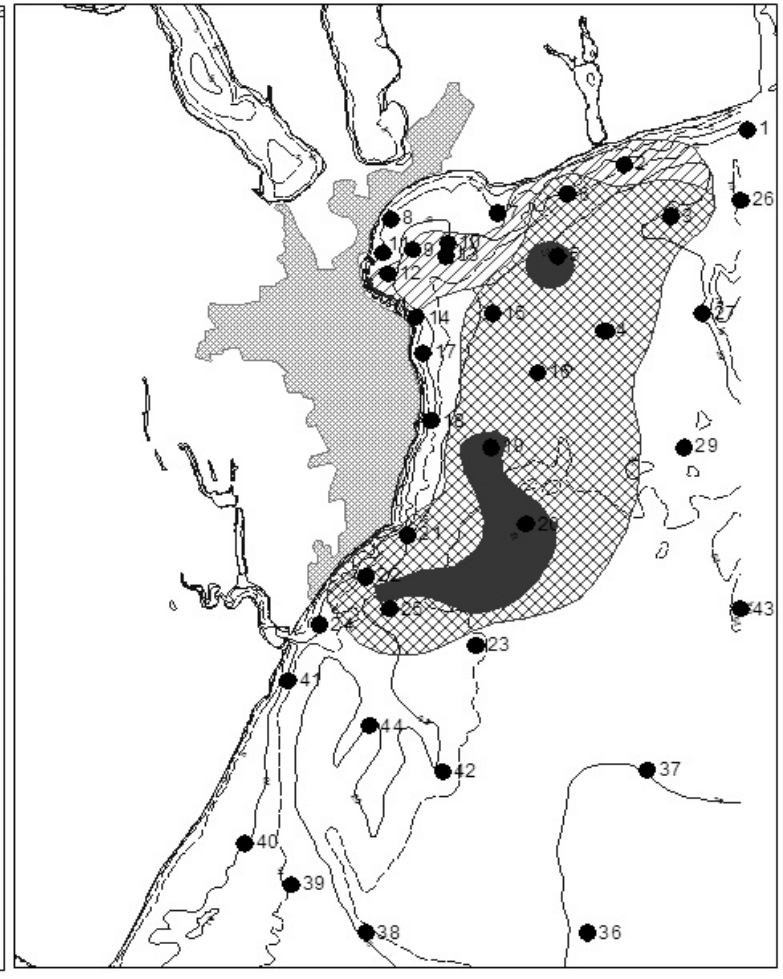

(b)

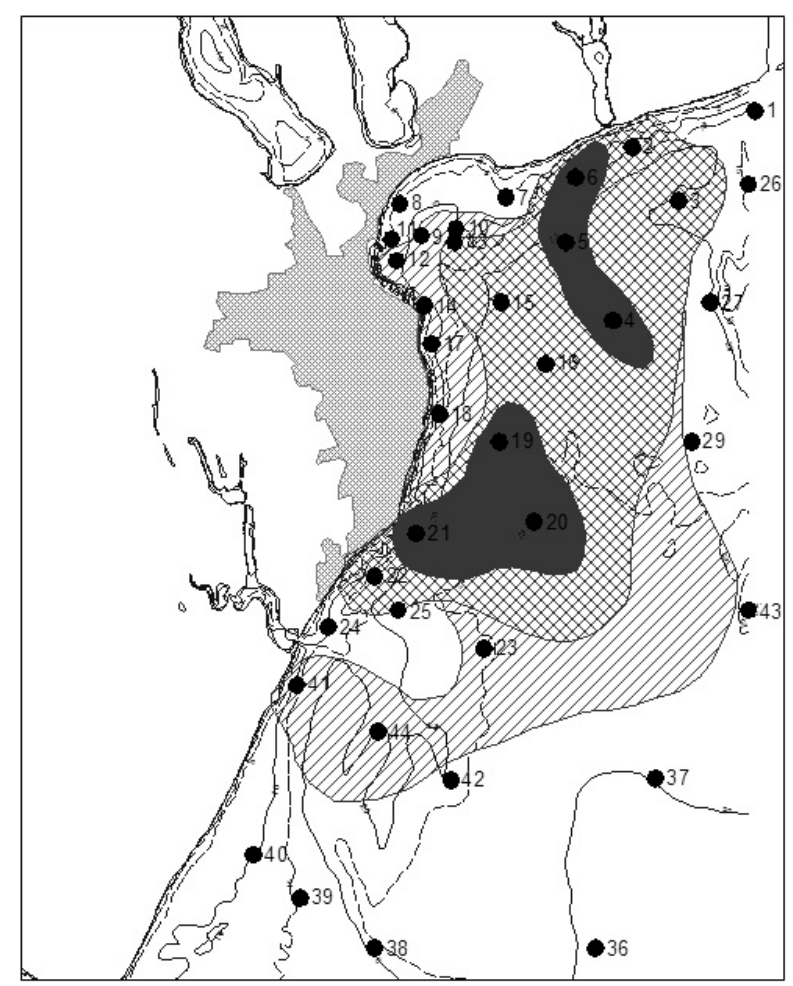

(c)

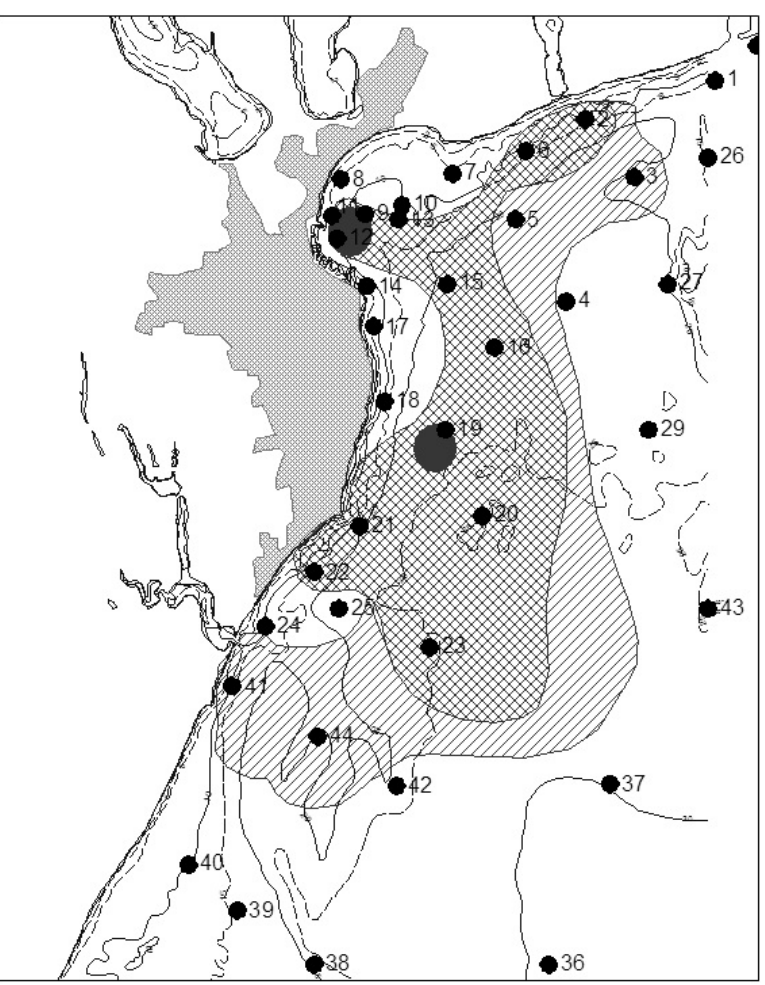

(d)

Fig. 5 Spatial distribution: A:copper, B: zinc, C: nickel, D: cadmium in the Odessa Region of the Black Sea in 2010. 


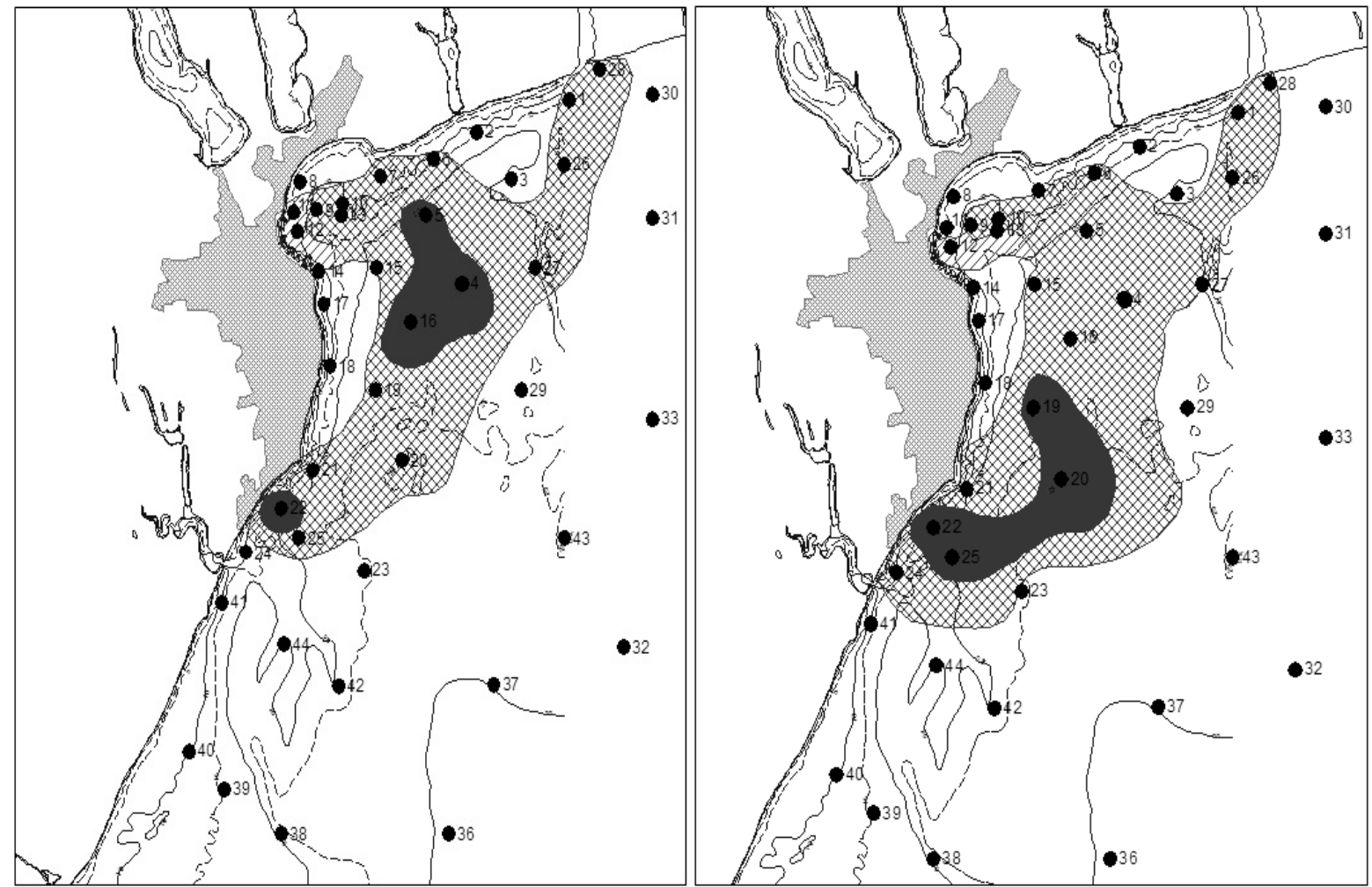

(a)

(b)

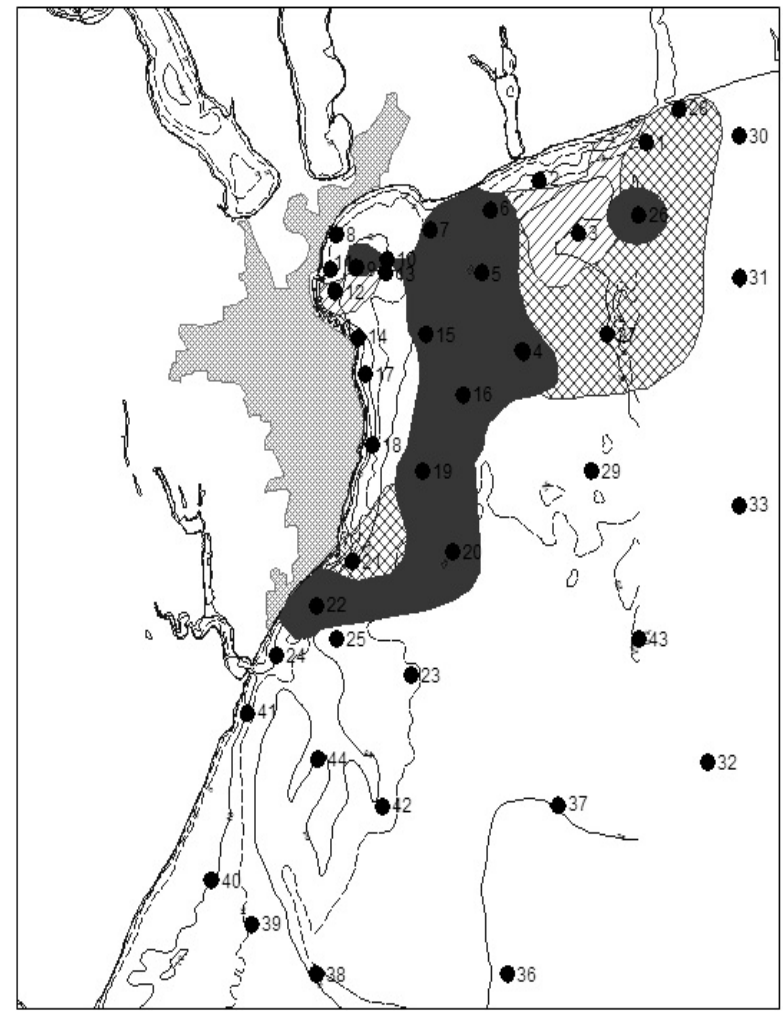

(c)

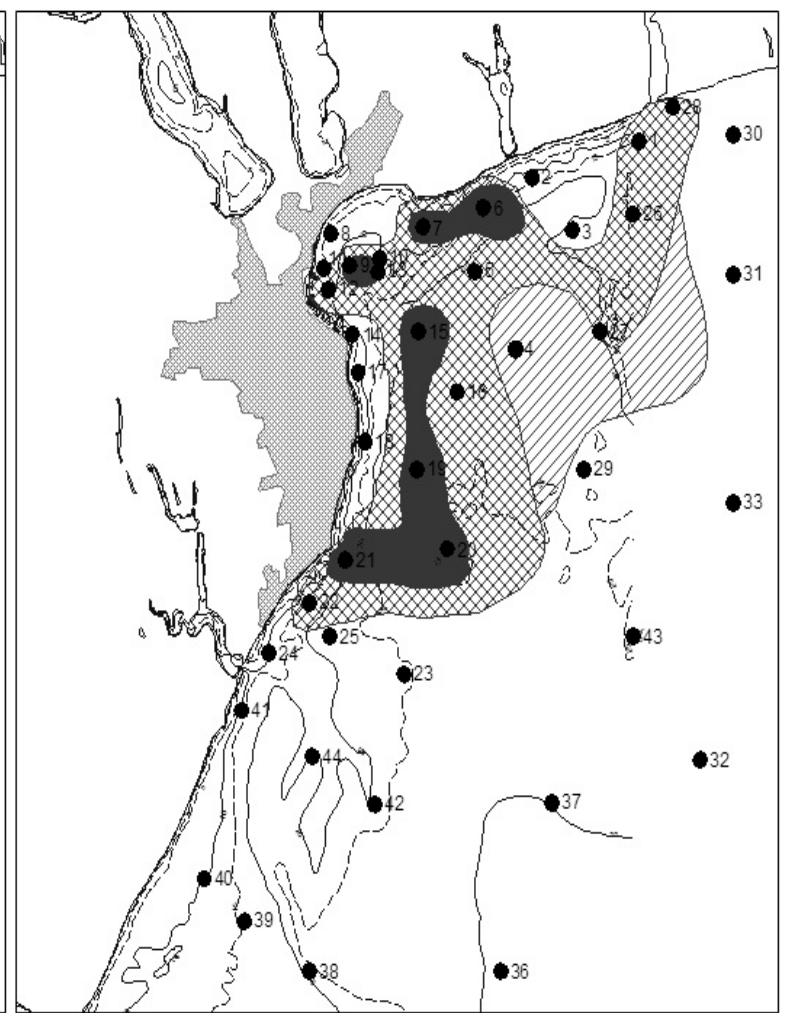

(d)

Fig. 6 Spatial distribution: A: copper, B: zinc, C: nickel, D: cadmium in the Odessa Region of the Black Sea in 2011. 
Table 1 Basic statistics of heavy metals in bottom sediments of the Odessa Region of the Black Sea

\begin{tabular}{lllllrrrrrrrr}
\hline & \multicolumn{3}{c}{2009 г. } & \multicolumn{1}{c}{2010 г. } & \multicolumn{3}{c}{$2011 г}$. \\
\cline { 2 - 14 } & $\min$ & $\max$ & $\operatorname{mean}$ & $\log \delta$ & $\min$ & $\max$ & $\operatorname{mean}$ & $\log \delta$ & $\min$ & $\max$ & $\operatorname{mean}$ & $\log \delta$ \\
\hline $\mathrm{Cu}$ & 8.0 & 47.7 & 20.6 & 1.06 & 0.1 & 6.6 & 38.10 & 1.30 & 1.1 & 65.2 & 40.58 & 1.23 \\
$\mathrm{Zn}$ & 20.3 & 75.3 & 52.5 & 1.19 & 3.9 & 75.8 & 46.46 & 1.34 & 5.6 & 75.0 & 47.36 & 1.26 \\
$\mathrm{Ni}$ & 12.6 & 31.1 & 24.0 & 0.75 & 12.6 & 76.6 & 51.69 & 1.26 & 22.1 & 79.6 & 50.76 & 1.20 \\
$\mathrm{Cd}$ & 1.5 & 17.0 & 3.5 & 0.63 & 0.3 & 2.9 & 1.22 & -0.17 & 0.2 & 2.9 & 1.74 & -0.17 \\
\hline
\end{tabular}

Table2 The area of the Odessa Region occupied by different classes of pollution $\left(\mathrm{km}^{2}\right)$.

\begin{tabular}{lllll}
\hline Classes of pollution & $C u$ & $Z n$ & $N i$ & $C d$ \\
\hline 2009 & & & & - \\
\hline I & 59.18 & 19.44 & 18.84 & - \\
II & 27.48 & 88.56 & 36.33 & 3.36 \\
III & 5.26 & 34.24 & 66.68 & 3.36 \\
\hline$\sum$ & 91.92 & 142.24 & 121.85 & 89.03 \\
\hline 2010 & & & & 103.36 \\
I & 62.28 & 21.04 & 98.76 & 5.14 \\
II & 94.13 & 117.59 & 111.03 & 197.53 \\
III & 23.37 & 15.21 & 30.37 & 38.87 \\
$\sum$ & 179.78 & 153.84 & 240.16 & 107.25 \\
\hline I & & & & 29.25 \\
II & 7.76 & 6.25 & 19.68 & 175.37 \\
III & 108.85 & 139.28 & 45.27 & 65.03 \\
$\sum$
\end{tabular}

of the Odessa Region of the Black Sea has increased dramatically due to the precipitation of a record rainfall (740 $\mathrm{mm}$ per year, that was twice the norm) (Fig.1).

Maps of the distribution of heavy metals in the Odessa Region of the Black Sea in 2009-2011 are shown in Figs. 4-6.

Basic statistics are given in Table 1. The sizes of areas occupied by I, II, and III classes of heavy metals are described in Table 2.

As seen in Table 2, in 2010 the area occupied by three classes of pollution significantly increased compared to 2009: copper: $95.58 \%$, zinc: $8.16 \%$, nickel: $97.09 \%$ and cadmium: 54.87 times. In 2011, the area occupied by three classes of contamination was $77.63 \%$ for copper, $112.23 \%$ for zinc, $54.12 \%$ for nickel and $88.78 \%$ for cadmium.

\section{Conclusion}

Studies have shown that the nature of the spatial distribution of heavy metals is subject to inter-annual variability under the influence of various factors. It was found that copper and nickel arrive in the Odessa Region of the Black Sea mainly from the catchment area, and the distribution of zinc and nickel in sediments has autochthonous character. In addition, in 2010 the average copper content of the sediments of the Odessa Region of the Black Sea has increased 1.59 times compared to 2009 [8]. This is due to the flow of copper from the catchment area where there are the largest plantations of grapes in the South of Ukraine, for the protection of which against diseases copper preparation is widely used.

\section{References}

[1] Naukova Dumka 2006. Northwestern Part of the Black Sea: Biology and Ecology. (in Russian).

[2] Dyatlov S.Ye. 2001. "Ecological and Toxicological Assessment of Marine Bottom Sediments." Vistnyk ONU (June) :88-95 (in Ukrainian).

[3] Dyatlov S.Ye. and Tuchkovemko Yu.S. 2002. "Methods 
of Assessing the Role of Bottom Sediments as a Source of Secondary Pollution of the Water Environment Using Mathematical Modeling." Ecological Safety of Coastal and Shelf Areas and Comprehensive Utilization of Resources of the Shelf. (in Russian).

[4] Dyatlov S.Ye. and Makovetskaya I.M. 2013. "Heavy Metals in Water and Bottom Sediments of Odessa Region of the Black Sea." Black Sea-Challenges towards good environmental status: 4th Bi-annual Scientific Conference. (Abstract).

[5] Fashchuk D.Ya. 2011. Marine Ecological Geography: Theory and Experience. Springer, 431.

[6] Cogan C.B., Todd B.J., Lawton P. and Noji T.T. 2009. "The role of Marine Habitat Mapping in Ecosystem-based Management." Ices Journal of Marine Science, V.66 (9).

[7] Urbański J.F. 2003. GIS-based Mapping of Benthic
Habitats // Estuarine, Coastal and Shelf Habitats: 99-109.

[8] Dyatlov S.Ye., Petrosyan A.G., "Pavlova Ye.A. and Secundyak L.Yu. 2013. The Anomalously High Content of Copper in the Water and Sediments in 'Odessa Region NWBS' Polygon in June 2010.” Proceeding of Ternopil National Pedagogical University.

[9] Dyatlov S.Ye, Chepizhko A.V. and Urdya V.A. 2012. "Interannual Variability of Heavy Metals in Water and Sediments Range Odessa Region North-West of the Black Sea." Ecological Safety of Coastal Shelf Zones and Comprehensive Use of Shelf Resources, issue 26, Vol.1,. (in Ukrainian).

[10] Linnik P.M. and Zubenko I.B. 2000. "Role of Bottom Sediments in the Secondary Pollution of Aquatic Environments by Heavy-metal Compounds." Lakes and Reservoir: Research and Management, issue 5. 